\title{
Doomed tongue twisters
}

\author{
Jeong Yeon Kim, Sang Won Han
}

Department of Neurology, Sanggye Paik Hospital, Inje University College of Medicine Seoul, Republic of Korea

\section{Correspondence to} Professor Sang Won Han, swhan@paik.ac.kr

Accepted 8 May 2014
CrossMark

To cite: Kim JY, Han SW. BMJ Case Rep Published online: [please include Day Month Year] doi:10.1136/ bcr-2013-202781

\section{DESCRIPTION}

Occurrence of hypoglossal nerve palsy (HNP) accompanied with other cranial nerve palsies is not an uncommon finding. However, isolated HNP is a rare finding and represents a diagnostic challenge. ${ }^{1}$

A woman in her late $70 \mathrm{~s}$ was referred to the neurology department due to sudden onset of dysarthria. She had right breast cancer in 2003 and underwent mastectomy, local radiotherapy and adjuvant chemotherapy for regional metastasis. On neurological examination her tongue was hemiatrophy and deviated to the left side. The rest of the neurological examination was unremarkable. Brain MRI showed a subtle enhancing lesion involving the left occipital condyle with the destruction of the petrous apex and clivus (figure 1A). The supraclavicular lymph node biopsy showed a metastatic adenocarcinoma (clinically breast ductal carcinoma).

In another case, a woman in her mid $60 \mathrm{~s}$ visited a hospital due to sudden onset of dysarthria. Medical history was unremarkable. Neurological examination showed atrophy with left-sided tongue deviation. Brain MRI revealed an enhancing lesion involving the left occipital condyle and clivus (figure 1B). The biopsy of regional enlarged lymph node showed the poorly differentiated metastatic squamous cell carcinoma.
The hypoglossal nerve is a pure motor nerve responsible for the motor supply to the tongue. Vascular, inflammatory, traumatic or spaceoccupying lesions can affect the hypoglossal nerve anywhere in its course. ${ }^{12}$ Isolated HNP is a rare finding because of its proximity to other important anatomical structures throughout its pathway. HNP, when isolated, may be the first sign of a serious underlying disease and a neoplastic aetiology should be excluded. ${ }^{2} 3$

\section{Learning points}

- Isolated hypoglossal nerve palsy is a rare finding because of its proximity to other important anatomical structures throughout its pathway.

- Vascular, inflammatory, traumatic or space-occupying lesions can affect a hypoglossal nerve anywhere in its course.

- Isolated hypoglossal nerve palsy may be the first sign of a serious underlying disease and a neoplastic aetiology should be excluded.

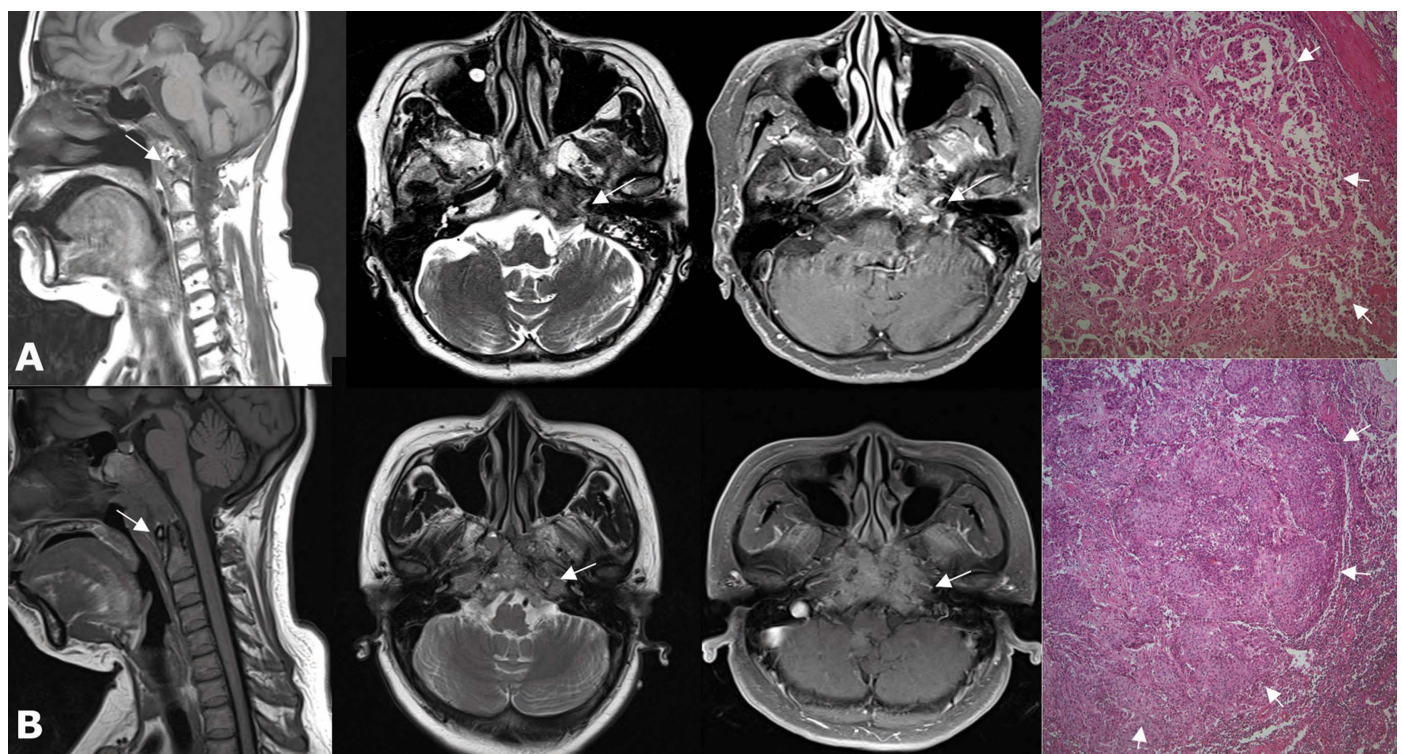

Figure 1 (A) Brain MRI showing bone marrow signal change with enhancing lesion located beneath the left occipital condyle and hypoglossal canal aperture (arrow). Pathologic findings of supraclavicular lymph node demonstrating metastatic adenocarcinoma showing gland forming tumour cells with cellular pleomorphism (arrows, H\&E stain $\times 100$ ). (B) Brain MRI revealing bone marrow signal change with expansive formation beneath the base of the skull located between the jugular foramen and foramen magnum and destroying the left occipital condyle and clivus (arrow). Pathologic findings of lymph node demonstrating metastatic squamous cell carcinoma showing diffuse irregular sheet with keratin (arrows, H\&E stain $\times 100$ ). 
Contributors JYK conceived and wrote this article. SWH supervised this article.

Competing interests None.

Patient consent Obtained.

Provenance and peer review Not commissioned; externally peer reviewed.

\section{REFERENCES}

1 Boban $M$, Brinar VV, Habek $M$, et al. Isolated hypoglossal nerve palsy: a diagnostic challenge. Eur Neurol 2007;58:177-81.

2 Fernandes R. Metastatic disease causing unilateral isolated hypoglossal nerve palsy. BMJ Case Rep 2010;2010;pii: bcr0520102998.

3 Pavithran $\mathrm{K}$, Doval DC, Hukku S, et al. Isolated hypoglossal nerve palsy due to skull base metastasis from breast cancer. Australas Radiol 2001:45:534-5.

Copyright 2014 BMJ Publishing Group. All rights reserved. For permission to reuse any of this content visit

http://group.bmj.com/group/rights-licensing/permissions.

BMJ Case Report Fellows may re-use this article for personal use and teaching without any further permission.

Become a Fellow of BMJ Case Reports today and you can:

- Submit as many cases as you like

- Enjoy fast sympathetic peer review and rapid publication of accepted articles

- Access all the published articles

- Re-use any of the published material for personal use and teaching without further permission

For information on Institutional Fellowships contact consortiasales@bmjgroup.com

Visit casereports.bmj.com for more articles like this and to become a Fellow 